Article

\title{
The Effect of Capital Structure on Firms' Profitability (Evidenced from Ethiopian)
}

\author{
Tariku Negasa \\ Department of Accounting \& Finance, Wollega University, Ethiopia; negasa2013@gmail.com
}

\begin{abstract}
This study was aimed to investigate the effect of capital structure on firms' profitability with special emphasis on Ethiopian Large Private Manufacturing Firms using panel data of five consecutive years (2006/07-2010/11G.C). The secondary data sources (audited financial statements) have been collected from the randomly selected thirty three large private manufacturing firms in Ethiopia. Linear regression model has been employed to analyze the relationship between firms' profitability and capital structure. Specifically, Random-effect Generalized Least Square of panel data regression model has been selected to empirically test the literature driven hypotheses. Finally, the findings of this study revealed that a significant positive relationship between firms' profitability and total debt ratio which indicate firm's capital structure.
\end{abstract}

Keywords: capital structure; total debt ratio; profitability; return on assets; firms; Ethiopia

\section{Introduction}

In today's competitive and dynamic business world, financial decision plays a fundamental role in the firm's day to day performance and operations. Firm's financial decision affects almost all activities within the company. In the field of corporate finance, capital structure decision is the most debatable issue for academicians and practitioners of corporate finance starting from a seminar work of Modigliani and Miller in 1958. Modigliani and Miller (1958) stated that the firm's value is independent from their capital structure decision, by assuming unrealistic assumptions on the real world; such as no corporate taxes, no transaction cost, and perfect capital market. However, Modigliani and Miller (1963) incorporated corporate taxes into their earlier assumption and they stated that optimal capital structure can be attained from 100 per cent debt financing through getting tax saving advantage of using debt. However, the second proposition also not considered the disadvantages of using more debts, such as bankruptcy cost and default risk.

After the work of Modigliani and Miller (1958 \& 1963) a number of theories have been developed to explain optimal capital structure of the firms. Agency cost theory, static trade-off theory, and pecking order theory are the most popular theories of capital structure. However, both debt and equity finance have their own merits and demerits. The merits of debt financing are tax-shield, disciplinary tool and cheapest sources of finance, while bankruptcy cost and default risks are its disadvantage. In the case of equity share, its advantage is there is a low probability of bankruptcy cost, while no tax advantage, costly and difficulty of controlling free cash flow are its disadvantages.

\section{Statement of the Problem}

The choice of capital structure is a critical point for the firm's financial decision makers; since it affects Earnings before Interest and Tax and leads to change in market value of the firm and share value. However, academicians and practitioners of corporate finance were not found the optimal capital structure which increases firm's profitability by reducing cost of capital. Hereby, static tradeoff theory of capital structure state that a value maximizing firm will consider the trade-off between the tax shelter provided by debt and the cost of financial distress. Mean that firms select optimal capital structure by examining the net tax advantage of debt financing by comparing advantages and 
disadvantage of debt finance (Brealey \& Myers, 2003). In addition, agency costs theory explains that one of the problems that cause conflict between managers and shareholders is free cash flows.

Jensen (as cited in Saleyi and Biglar, 2009) defines debts as a disciplinary tool to ensure that managers give preference to wealth creation for the shareholders. Those companies having high profitability and free cash flow available in the hands of managers, increasing of debts can be used as a tool of reducing the scope for managers until resources of company may not be misuse as a result of their individual interests (Jensen \& Meckling, 1976). Furthermore, pecking order theory stated that firms have a perfect hierarchy for financing decisions, i.e. first choice is to use internal financing, next issues debt finance if internal source fund is not sufficient to finance the firm, and equity finance should be the last resort of financing the firm (Rasian \& Kim, 2011).

If the above three points are working for the developed countries those having access to choice of debt finance, what is the effect of low debt finance on profitability of Ethiopian firms where there is lack of debt finance i.e. no corporate bond and commercial banks are unwilling to lend long term loan. These are the major gaps identified by the researcher and encourages to study on the title.

In general, the objective of this study was to investigate the effect of capital structure on the profitability of Ethiopian large private manufacturing firms.

\section{Literature Review}

\subsection{Theories of Capital Structure}

Static Trade-off Theory: It centers on the repayment and costs of issuing debt and it predicts that an attractive target debt ratio is to make a good value to the company. The best combination may be achieved when the marginal value of the payback is linked with debt concerns exactly offsets the raise in the present value of the costs correlated by handing out more debt (Myers, 2001). The main benefit of debt is the tax deductibility of interest payments. The tax deduction of corporate interest payments favors the application of debt (Rasian \& Kim, 2011). According to this theory, other benefit of debt finance is to control the difference of interest between managers and shareholder. Corporate managers have the incentive to misuse free cash flow on perquisites and inefficient investment decisions. Debt financing confines the free cash flow available to managers and by this means to control these firms' difficulties. The costs associated with issuing debt are cost of financial distress (Modigliani \& Miller, 1963) and costs incurred by the firm at the time conflicts between shareholders and debtors (Jensen \& Meckling, 1976).

Agency costs theory: Agency costs rises from separation of ownership and control and conflicts of interest between managers and shareholders. One of the problems that cause conflict between managers and shareholders is free cash flows. Jensen, 1976 (as cited in Saleyi \& Biglar, 2009) defines debt as a disciplinary tool to ensure that managers give preference to wealth creation for the equity-holders. The companies that have high cash flow and profitability, increasing of debts can be used as a tool of reducing the scope for managers until resources of company may not be waste as a result of their individual purposes. The other conflicting problem is that managers may not receive all the benefits of their activities. This is seen when manager's share in ownership of company is low. When the manager's increase stock is high, this inefficiency decreases (Saleyi \& Biglar, 2009).

Additional costs of debt include potential bankruptcy costs, and agency costs associated with the monitoring of investments by bondholders. Costs and benefits of alternative financial sources are "traded off" until the marginal cost of equity equals the marginal cost of debt, yielding the optimal capital structure, and maximizing the value of the firm. Jenson (as cited in Saleyi and Biglar, 2009) stated that the conflict between benefits of share holders and creditors has consequences like increase of interest rate by creditors, addition of supervision costs and decrease of investment. So, this conflict demonstrates that high leverage leads to poor performance.

Pecking Order Theory: It states that firms have perfect hierarchy for financing decisions. The best first choice is to use internal financing which are retained earnings, and then issues debt securities if internal source fund is not sufficient to finance the firm and issue of equity is the last choice of financing the firm. Internal funds incur no flotation costs and require no supplementary 
admission of proprietary financial information that could show the way to more strict market regulation and possible losses of great competitive advantage (Rasian \& Kim, 2011). According to Myers (1984) firms must use external funds and he suggested that the first choice is to use the financing sources such as debt, convertible securities, preferred stock, and common stock.

Asymmetric information is deep-rooted in the pecking order theory, or the likelihood that a firm's managers know more about the company's financial condition and future growth opportunities than do outside investors. There are strong needs to keep such information appropriately. The use of internal funds prevents managers from having to make public disclosures about the company's investment opportunities and potential revenue to be realized from investing into them. The second supposition is that managers will proceed in the welfare of the company's existing shareholders. The managers may still give up or reject a positive NPV project. Consequently, it would require the issue of new equity or a large amount of capital, since this would give much of the project's value to new shareholders (Myers \& Majluf, 1984).

Free Cash Flows Theory: It argues that firms seek to maintain dangerously high levels of debt because they believe these high levels will increase value, despite the threat of financial distress. Free cash flows occur when a firm's operating cash flow significantly exceeds its profitable investments and is a common practice for mature firms that are prone to over-invest (Myers, 2001). According to Brealey, Myers and Marcus (1995), the free cash flow theory predicts that mature, cash cow companies are the most likely targets for leveraged buyouts, yet they do not endorse this theory as the sole explanation for the existence of leveraged buyouts.

\subsection{Empirical Evidence}

Many empirical studies have been made around the globe to analyze the relationship between capital structure and firm's profitability. In Jordan, Zeitun and Tian (2007) investigated the effect which capital structure has on corporate performance and their result showed that a firm's total debt ratio had significant negative impact on the firm's performance measures, in both the accounting and market's measures. Their results further indicated that variable firm's growth and firm's size have a significant positive influence on the firm's profitability, while assets tangibility negatively related with firm's performance in their study. Kyereboah-Coleman (2007) confirmed that a positive relationship between total debt ratio and profitability. Similarly, Abor (2005) also explained that there is a significant positive relationship between short term debt and return on equity, and it suggests that profitable firms use more short-term debt to finance their operation. However, the same study showed a negative relationship between long-term debt and ROE, there was a significant positive relationship between total debt ratio and ROE.

In Brazilian, Mesquita and Lara (2003), the study revealed a negative relationship between the profitability variable and long-term debt ratio and they conclude that the larger the debt the lower the profitability. However, short-term debt presented a positive relation with profitability. Similarly, Obert and Olawale (2010) made the similar study and found that there was insignificant relationship between debt ratio and profitability of the firms, and they recommended that the selection of debt as a source of capital finance should be done in line with the costs and benefits associated with the use of debt. Zerah, 2011; Adekunle and Sunday, 2010; Zeitun and Tian, 2007Abu-Rud, 2012; and Raheman et al, 2007 were also tested the effect of capital structure on firms' profitability.

\section{METHODOLOGY}

\subsection{Data Source and Sampling}

The study has employed panel data which were collected from 33 large private manufacturing firms in Ethiopia for a five consecutive years study period (2006/07-2010/11 G.C) and quantitative data were used which have been collected from secondary sources. Secondary data were gathered from audited financial statement of large private manufacturing firms in Ethiopia. Moreover, the study employed simple random sampling techniques to select 33 sample firms out of 36 large private 
manufacturing companies. Here, simple random sampling was used to give the equal chance of being selected for targeted firms.

\subsection{Method of Data Analysis}

Regression analysis is used to investigate the relationship between firms' capital structure indicator and profitability. Particularly, Random-effect GLS regression model has been employed to analyze the relationship between dependent variable (ROA) and independent variables (debt ratio, growth rate, firm size, assets tangibility, liquidity and non-debt tax shield) and to analyze the effect of capital structure on firms' profitability.

\subsection{Model Specification}

For this study, based on the result of model specification tests, the random-effect GLS regression model of panel data has been selected to analyze the relationship between dependent variable ROA as measures of firm's profitability and independent variable total debt ratio (TDR) as proxy of capital structure. In the model, controlled variables growth rate (GROW), firm's size (SIZE), Tangibility of assets (TANG), liquidity (LIQU) and non-debt tax shield (NDTS) were also incorporated. Therefore, the specific panel data regression model for this study was represented as follows:

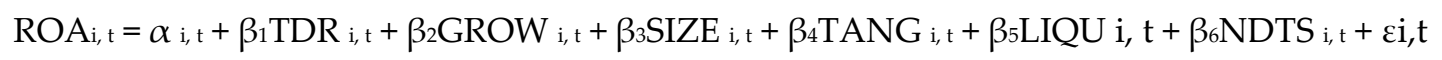

Where:

$\boldsymbol{\beta} 1$ is the co-efficient for total debt ratio

$\boldsymbol{\beta} 2$ is the co-efficient for growth rate

$\beta 3$ is the co-efficient for firms' size

$\beta 4$ is the co-efficient for tangibility

$\beta 5$ is the co-efficient of firms, liquidity

$\beta 6$ is the co-efficient of tax-shield

$\varepsilon \mathbf{i}, \mathbf{t}$ is error terms

\subsection{MAJOR FINDINGS OF THE STUDY}

Out of the six explanatory variables, four of them (total debt ratio, growth, size and liquidity) are found to be significant at less or equal to $10 \%$ level of significance, while two variables (tangibility and non-debt tax shield) are found as insignificant.

As indicated in Appendix 1, total debt ratio (TDR) variable used as a proxy of firms' capital structure has a positive correlation coefficient (0.139) with variable profitability which measured by ROA, at p-value of 0.018 (significant at 5\%), other thing remains constant. This result is consistent with the relevance theory of capital structure (Modigliani and Miller, 1963). The theory suggests that firms can use debt to lower their cost of capital and maximize the firm's value. The result is also consistent with the findings of prior empirical studies such as Abu-Rud (2012), KyereboahColeman (2007), Abor (2005) and Zerah (2011). In contrast, the studies made by Zeitun and Tain (2007), Mesquita and Lara (2003) and Ebaid (2009), become inconsistent result with this study.

The other variable that has a significant effect on firms' profitability is growth (GROW) of the companies during the study period. As indicated in Appendix 1, variable firm's growth has a significant positive relationship with firms' profitability, which is approved by coefficient of correlation value of 0.15 and $1 \%$ level of significance, keeping other things constant. The result is consistent with Zeitun and Tain (2007), Abor (2005), Ammar et al, (2003), and Adenkule and Sunday (2010).

The outcome of the model also showed a positive relationship between variable firm's size and ROA with a coefficient of 0.098 and p-value of 0.000 , citrus paribus. It implies that, the more the firms' 
become larger, the more it gains the higher profit and vice versa. The finding of this study is consistent with the prior studies, those found a positive relation between size and ROA, such as Raheman et al. (2007), Zeitun and Tain (2007) and Abor (2005).

The result of econometric model showed that controlled variable assets tangibility (TANG) has a positive coefficient of 0.054 , but not significant in the robust regression model, keeping other thing constant. This showed that having larger fixed assets is less important in affecting the profitability, indirectly less on Ethiopian firms' capital structure.

Moreover, Appendix 1 indicated that variable liquidity (LIQU) has a significant negative relationship with profitability measure of ROA. As indicated in the regression result table, the relationship between ROA and liquidity is negative and significant at $5 \%$ level of significance, citrus paribus. The result is consistent with agency cost theory which stated that having large amount of free cash flow reduces firm's profitability since managers may use it for their individual purpose and suggests debt finance as a disciplinary tool. In similar direction, the prior empirical studies such as Graf (2010), and Saleem \& Rahman (2011).

The regression result also revealed a positive relation between profitability and non debt tax shield (NDTS) by coefficient of correlation value of 0.087 , but not statistically significant in the model.

Finally, from panel data regression result (Appendix 1), the estimated regression equation has been developed as follows:

$\mathrm{ROA}=-0.79+0.139(\mathrm{TDR})+0.15(\mathrm{GROW})+0.098(\mathrm{SIZE})+0.054(\mathrm{TANG})-0.008(\mathrm{LIQU})+0.087(\mathrm{NDTS})$ $+\varepsilon i, t$

\section{Conclusions and Recommendations}

From the major findings of this study; the following conclusions are drawn, thereafter recommendations were forwarded to the stakeholders:

There is a considerable positive relation between total debt ratio and profitability in Ethiopian large private manufacturing firms should have to search the optimal capital structure that fit for their respective firm by increasing debt ratio. Static trade-off theory predicts a positive correlation between profitability and debt ratios, since high performance firms have less expected bankruptcy costs. However, there is a question "what proportion is optimal?" Brigham and Gapenskiz (1996) suggested that the managers of the firm should be able to identify when the optimal capital structure is attained and try to maintain it at that level. Nevertheless, when searching for optimal capital structure to reduce costs of capital, financial managers should have to consider the risk of bankruptcy cost that may exist from an excessive use of debt finance.

After attaining their respective optimal capital structure, Ethiopian large private manufacturing firms should have to look for the variables having significant positive effect on their profitability such as growth and size. Here, considering the proportion at which optimal capital structure is attained as a targeted capital structure, owners and managers should have to work for enlarging firm's growth and size through rising additional capital (debt and owners fund) to improve their profitability. Using sustainable growth rate, managers and investor can start to judge whether or not the firm's future growth plans are reasonable based on their current performance and policy.

On the other hand, since Ethiopian large private manufacturing firms were suffered from maintaining higher level of liquid assets, financial managers of firms' should have to readjust level of their liquidity ratio. In order to improve the firm's profitability, the reduction of liquidity ratio shall be made by means of reducing the amount of current assets. However, reduction of liquidity ratio should not be less than the standard ratio of 2 to 1 .

\section{Direction for the further researchers}

The sample of this study was only focused on large private manufacturing firms those registered under ERCA. Thus, the outcome of this study may not represent the result from all other sectors in Ethiopia. Moreover, in order to come with a more comprehensive results other proxies of capital structure such as long-term debt to total assets, short-term debt to total assets, and debt to equity 
ratio shall be captured in the model and other measures of profitability such as ROE, operating margin and earning per shares can be used to develop additional model. The study also didn't considered macro level factors such as inflation and interest rate.

\section{References}

1. Abor, J. (2005). The effect of capital structure on profitability: An empirical analysis of listed firms in Ghana. The Journal of Risk Finance, 6(5), 438-447.

2. Abu-Rub, N. (2012). Capital structure and firm performance: Evidence from Palestine Stock Exchange. Journal of Money, Investment and Banking, (23), 109-117.

3. Adekunle, O. A., \& Sunday, K. O. (2010). Capital structure and firm performance: Evidence from Nigeria. European Journal of Economics, Finance and Administrative Sciences, (25), 70-82.

4. Ammar, A., Hanna, A. S., Nordheim, E. V., \& Russell, J. S. (2003). Indicator variables model of firm's size-profitability relationship of electrical contractors using financial and economic data. Journal of Construction Engineering and Management, 192-197. doi:10.1061/(ASCE) $\quad 0733$-9364(2003)129:2(192).

5. Brealey, R. A., \& Myers, S. C. (2003). Principles of corporate finance. International edition. Boston, McGrawHill, MA.

6. Brigham, E. F. \& Gapenski, C. L. (1996). Financial management: Theory and practice (6 $6^{\text {th }}$ ed.). London, British, Dryden Press.

7. Ebaid, I. E. (2009). The impact of capital-structure choice on firm performance: Empirical evidence from Egypt. The Journal of Risk Finance, 10(5), 477-487.

8. Jensen, M., \& Meckling, W. (1976). Theory of the firm: Managerial behavior, agency costs and ownership structure. Journal of Financial Economics, 3(4), 305-360.

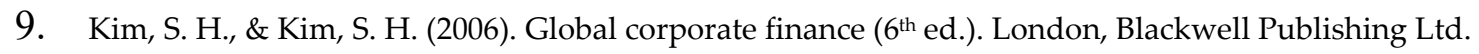

10. Kyereboah-Coleman, A. (2007). The impact of capital structure on the performance of microfinance institutions. Journal of Risk Finance, 8(1) 56-71. doi: 10.1108/152659- 40710721082.

11. Marsh, P. (1982). The choice between equity and debt: An empirical study. Journal of Finance, 37(1), 121144.

12. Mesquita, J. M. C., \& Lara, J. E. (2003). Capital structure and profitability: The Brazilian case. Academy of Business and Administration Sciences Conference.

13. Miller, M. H. (1977). Debt and taxes. Journal of Finance, 32, 261-76.

14. Modigliani, F., \& Miller, M. (1958). The cost of capital, corporate finance and the theory of investment. American Economic Review, 48(3), 261-297.

15. Modigliani, F., \& Miller, M. (1963). Corporate income taxes and the cost of capital: A correction. American Economic Review, 53(3), 443-453.

16. Myers, S. C. (1984). The capital structure puzzle. Journal of Finance, 39, 575-592.

17. Myers, S. C. (2001). Capital structure. Journal of Economic Perspectives, 15(2), 81-102.

18. Myers, S. C., \& Majluf, N. S. (1984). Corporate financing and investment decisions when firms have information that investors do not have. Journal of Financial Economics, 12, 187-221.

19. Obert, M. \& Olawale, F. (2010). Does debt really matter on the profitability of small firms? a perspective on small manufacturing firms in Bulawayo, Zimbabwe. African Journal of Business Management. 4(9), 17091716.

20. Pandey, I. M. (2004). Capital structure, profitability and market structure: Evidence from Malaysia. Asia Pacific Journal of Economics \& Business, 8(2), 78 - 91

21. Paramasivan, C., \& Subramanian, T. (2009). Financial management. Daryaganj, India: New age international Ltd, publishers.

22. Petersen, M. A., \& Rajan, R. G. (1994). The benefits of lending relationships: evidence from small business data. Journal of Finance, 49, 3-37.

23. Prahalathan, B. (2010). The determinants of capital structure: An empirical analysis of listed manufacturing companies in Colombo stock exchange market in SriLanka. Unpublished journal article, Faculty of commerce \& management studies, University of Kelaniya, SriLanka.

24. Raheman, A., Zulfiqar, B., \& Mustafa. (2007). Capital structure and profitability: Case of Islamabad stock exchange. International Review of Business Research Papers, 3(5), 347-361. 
25. Rajan, R. G., \& Zingales, L. (1995). What do we know about capital structure? Some evidence from international data. Journal of Finance, 50(5), 1421-1460.

26. Rasiah, D., \& Kim, P. K. (2011). A theoretical review on the use of the static trade off theory, the pecking order theory and the agency cost theory of capital structure. International Research Journal of Finance and Economics, 63, 150-159.

27. Saleyi, M., \& Biglar, K. (2009). Study of the relationship between capital structure measures and performance: Evidence from Iran. International Journal of Business and Management, 4(2), 97-103.

28. Zerah, W. Z. (2011). The effect of capital structure on financial performance: Evidence from commercial banks in Ethiopia. (Master thesis, at Mekelle University, Management department).

29. Zeitun, R., \& Tian, G.G. (2007). Capital structure and corporate performance: Evidence from Jordan. Journal of Australasian Accounting, Business \& Finance, 1(4), 40- 61.

\section{Appendix}

Appendix 1: Random-effect GLS Regression model of ROA and Independent Variables

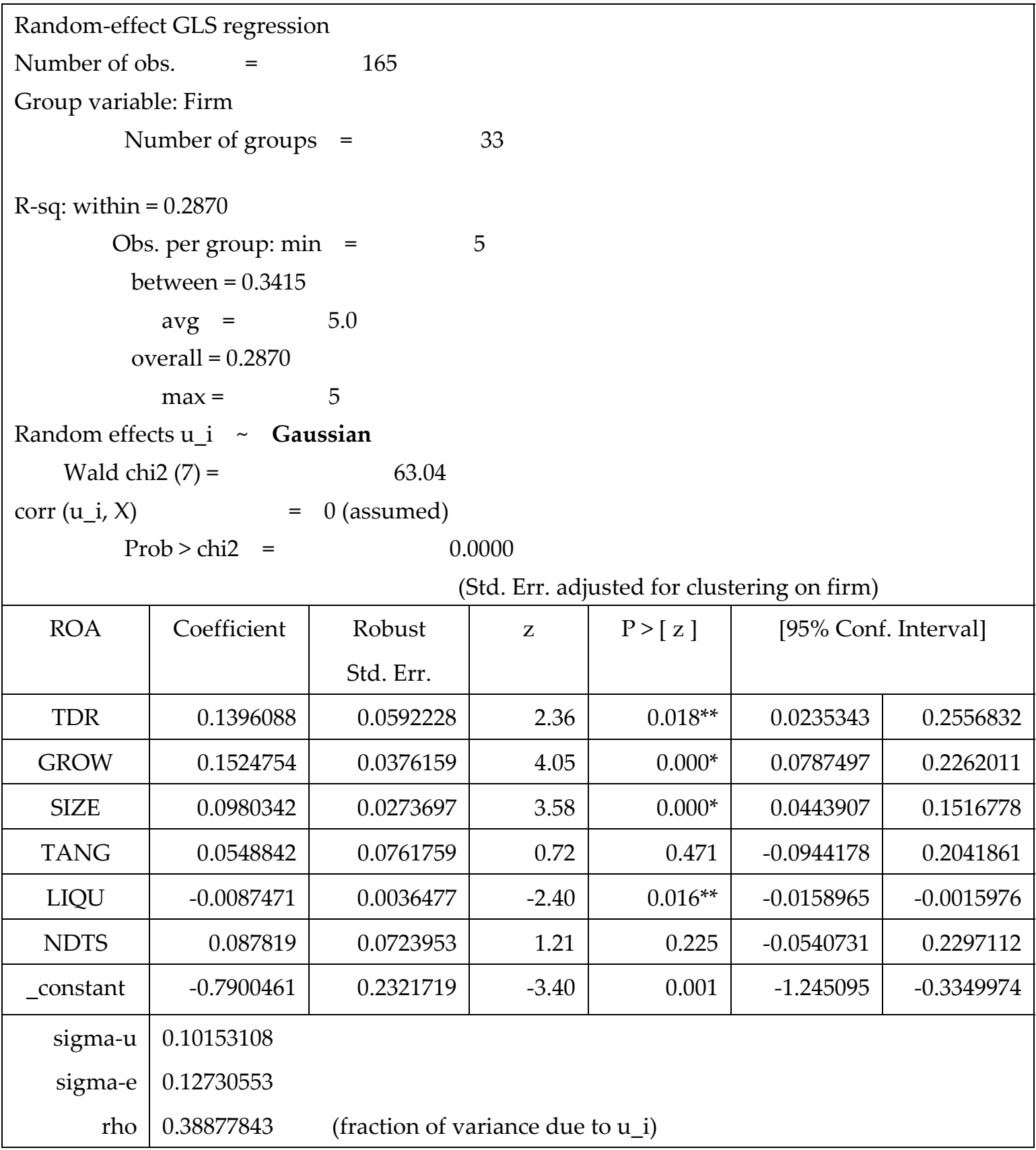

Source: Researcher's own computation using STATA 10.0 SE 
Note: corr $\left(u \_i, x\right)=$ explains the difference across units are uncorrelated with the repressor sigma_u = shows that the standard deviation of residuals within the groups $\left(u_{i}\right)$ sigma_ $\mathcal{E}_{=}$shows the standard deviation of residuals or error term ( $\left.\mathcal{E}_{i}\right)$ rho $=$ shows the coefficient of auto-covariance ${ }^{*}$ and ${ }^{* *}$ represents significance level at $1 \%$ and $5 \%$, respectively.

Appendix 2: Summary of Descriptive Statistics for five consecutive years' financial data

\begin{tabular}{|c|c|c|c|c|c|}
\hline Variable & $\begin{array}{c}\text { Number of } \\
\text { Observations }\end{array}$ & Mean & $\begin{array}{c}\text { Standard } \\
\text { Deviation }\end{array}$ & Minimum & Maximum \\
\hline ROA & 165 & 0.1040949 & 0.1873794 & -0.3266786 & 0.8893035 \\
\hline TDR & 165 & 0.4859377 & 0.2545499 & 0.0178415 & 0.99122 \\
\hline GROW & 165 & 0.2521091 & 0.2841524 & -0.872163 & 1.434013 \\
\hline SIZE & 165 & 7.721415 & 0.4665528 & 7.00299 & 9.507082 \\
\hline TANG & 165 & 0.6610721 & 0.2218877 & 0.0498683 & 0.9655125 \\
\hline LIQU & 165 & 2.628004 & 2.591426 & 0.3674082 & 17.69237 \\
\hline NDTS & 165 & 0.2004261 & 0.1963153 & 0.0009686 & 0.9727646 \\
\hline
\end{tabular}

Source:Researcher's onw computation using STATA 10.0 SE

Appendix 3: Pair-wise Correlation Matrix

\begin{tabular}{|c|c|c|c|c|c|c|c|}
\hline Variables & ROA & TDR & GROW & SIZE & TANG & LIQU & NDTS \\
\hline ROA & 1.00 & & & & & & \\
\hline TDR & $\begin{array}{l}0.2346 \\
(0.0024)^{*}\end{array}$ & 1.00 & & & & & \\
\hline GROW & $\begin{array}{l}0.4060 \\
(0.0000)^{*}\end{array}$ & $\begin{array}{l}0.1506 \\
(0.0535)^{* * *}\end{array}$ & 1.00 & & & & \\
\hline SIZE & $\begin{array}{l}0.3119 \\
(0.0000)^{*}\end{array}$ & $\begin{array}{l}0.0156 \\
(0.8421)\end{array}$ & $\begin{array}{l}0.2048 \\
(0.0083)^{*}\end{array}$ & 1.00 & & & \\
\hline TANG & $\begin{array}{l}0.1401 \\
(0.727)\end{array}$ & $\begin{array}{l}0.1008 \\
(0.1976)\end{array}$ & $\begin{array}{l}0.1104 \\
(0.1582)\end{array}$ & $\begin{array}{l}-0.0337 \\
(0.6674)\end{array}$ & 1.00 & & \\
\hline LIQU & $\begin{array}{l}-0.1972 \\
(0.0111)^{* *}\end{array}$ & $\begin{array}{l}-0.2234 \\
(0.0039)^{*}\end{array}$ & $\begin{array}{l}-0.1088 \\
(0.1643)\end{array}$ & $\begin{array}{l}0.0466 \\
(0.5522)\end{array}$ & $\begin{array}{l}-0.0542 \\
(0.4898)\end{array}$ & 1.00 & \\
\hline NDTS & $\begin{array}{l}0.0329 \\
(0.6748)\end{array}$ & $\begin{array}{l}-0.0975 \\
(0.2127)\end{array}$ & $\begin{array}{l}0.536 \\
(0.4940)\end{array}$ & $\begin{array}{l}-0.2469 \\
(0.0014)^{*}\end{array}$ & $\begin{array}{l}0.0129 \\
(0.8693)\end{array}$ & $\begin{array}{l}-0.1085 \\
(0.1655)\end{array}$ & 1.00 \\
\hline
\end{tabular}

Source: Researcher's own computation using STATA 10.0 SE 
Note: The numbers in brackets represents p-value;

${ }^{*}, * *, \mathcal{E}^{* * *}$ represents that at $1 \%, 5 \%, \mathcal{E} 10 \%$ significance level, respectively

- sign indicates negative correlation between the two variables

Appendix.4: Summary of Hypothesis Testing

\begin{tabular}{|l|l|c|l|}
\hline Independent Variables & $\begin{array}{l}\text { Hypothesized } \\
\text { Relationship of ROA } \\
\text { with Independent } \\
\text { Variables }\end{array}$ & $\begin{array}{c}\text { Actual Sign } \\
\text { (Actual } \\
\text { Relationship) }\end{array}$ & \multicolumn{1}{|c|}{ Decision } \\
\hline Total Debt Ratio & + & + & Accepted at $5 \%$ \\
\hline Growth & + & + & Accepted at $1 \%$ \\
\hline Firm's Size & + & + & Accepted at $1 \%$ \\
\hline Assets Tangibility & + & Insignificant & Rejected \\
\hline Liquidity & + & Insignificant & Rejected \\
\hline Non-debt Tax Shield & + & Accepted at $5 \%$ \\
\hline
\end{tabular}

Source: Researcher own design

Note: + sign represents a positive relationship with dependent variable (ROA)

- sign represents a negative relationship with dependent variable (ROA) 